\title{
DESAIN KURIKULUM LITERASI MEDIA BERMUATAN NILAI-NILAI ISLAM DI SEKOLAH MENENGAH ATAS AL IRSYAD SATYA
}

\author{
Rani Kurniasari dan Deni Kurniawan \\ Universitas Pendidikan Indonesia \\ e-mail: ranip4tkipa@gmail.com
}

\begin{abstract}
Abstrak
Pentingnya kompetensi literasi media bermuatan nilai-nilai Islam pada kegiatan ekstrakurikuler Pengembangan Diri (PD) di SMA Al-Irsyad Satya menjadi latar belakang penelitian ini. Sedangkan tujuan penelitian adalah dihasilkannya desain kurikulum literasi media bermuatan nilai-nilai Islam yang relevan pada kegiatan ekstrakurikuler PD di SMA Al-Irsyad Satya. Metode penelitian yang digunakan adalah Design \& Development dengan pendekatan kuantitatif. Desain kurikulum menghasilkan dokumen kurikulum literasi media bermuatan nilai-nilai Islam pada kegiatan ekstrakurikuler PD yang terdiri dari 27 tujuan pembelajaran, 21 materi/ konten pembelajaran, 17 strategi/ pengalaman belajar, dan 6 evaluasi pembelajaran. Pendapat stakeholder, dokumen kurikulum literasi media bermuatan nilai-nilai Islam pada kegiatan ekstrakurikuler PD di SMA Al-Irsyad Satya yang disusun layak untuk dipergunakan di SMA Al-Irsyad Satya karena memiliki relevansi yang memadai baik secara internal maupun eksternal.
\end{abstract}

Kata kunci: kurikulum literasi media, muatan nilai Islam, design \& development

\section{CURRICULUM DESIGN OF MEDIA LITERACY BASED ON ISLAMIC VALUES IN SMA AL-IRSYAD SATYA}

\begin{abstract}
This research is based upon the importance of the competency of media literacy which contains Islamic values on Self-Development's extracurricular activity in SMA Al-Irsyad Satya. The objective of this research is to formulate a curriculum design of media literacy which contains relevant Islamic values on Self-Development's extracurricular activity in SMA Al-Irsyad Satya. The methodology of this research is Design \& Development through quantitative approach. The conclusion of this research shows that in the need assessment stage there are 71 indicators of curriculum component that are relevant to use in curriculum design consists of 27 learning objectives, 21 learning contents, 17 learning strategies, and 6 learning evaluations. In the design stage, the draft of curriculum of media literacy which contains Islamic values is successfully formulated based upon need assessment. On the stakeholders review, it is clearly stated that the document of curriculum of media literacy which contains Islamic values on Self-Development's extracurricular activity in SMA AlIrsyad Satya is feasible to implement as it has relevance for both internal and external aspect.
\end{abstract}

Keywords: curriculum of media literacy, contain Islamic value, design \& development

\section{PENDAHULUAN}

Dunia telah mengalami perubahan dari masa ke masa. Perkembangan IPTEK sebagai salah satu aspek penggerak perubahan, telah menjadikan manusia kini berada pada era globalisasi. Globalisasi merupakan proses yang meliputi sebab, arah, dan konsekuensi dari sebuah integrasi transnasional dan transkultural dari aktivitas manusia dan lingkungannya (Rodhan, 2006).

Globalisasi sebagai sebuah bahasan kontemporer menjadikan dunia menjadi seolah berbaur tanpa sekat. Salah satu sisi 
positifnya, kemudahan mengakses media atau informasi dari berbagai belahan dunia menjadikan semakin bervariasinya cara untuk memudahkan kehidupan manusia.

Berdasarkan data penetrasi media di Indonesia, televisi menjadi media yang paling tinggi penetrasi atau penggunaannya. Sementara itu, media internet berada di urutan ketiga. Internet kini penggunanya semakin meningkat dari tahun ke tahun. Data statistik Asosiasi Penyelenggara Jasa Internet Indonesia (APJII, 2016) menunjukkan jumlah pengguna internet di Indonesia pada tahun 2016 adalah 132,7 juta dari total penduduk 256,2 juta. Angka pengguna internet tersebut mengalami pertumbuhan 51,8\% dari survey APJII 2014 yang mencatat 88 juta pengguna. Dari 132,7 juta pengguna internet tersebut, sebanyak 8,3 juta adalah pelajar, dan total $69,8 \%$ pelajar di Indonesia menggunakan internet (Kementerian Komunikasi dan Informasi, 2014).

Tingginya angka penggunaan media di antaranya televisi dan internet sebagai bagian globalisasi, tidak hanya berdampak positif, namun juga memiliki konsekuensi negatif. Berbagai budaya atau paham yang lebih dulu dimiliki bangsa lain seperti kapitalisme dan hedonisme, kini menjadi budaya yang marak ada di masyarakat kita. Pergaulan bebas, penyalahgunaan narkoba, serta banyaknya mindset materialistis, hedonis, dan pragmatis seperti perkelahian pelajar, menjadi beberapa contoh akulturasi budaya tersebut (Bobby, 2015). Berdasarkan data Komisi Perlindungan Anak Indonesia (KPAI, 2016) dari tahun 2011-2016, terdapat banyak kasus pengaduan anak dan angkanya cenderung meningkat dari tahun ke tahun.

Terdapat sebuah muara besar yang menghubungkan sebab dari fenomenafenomena krisis moral yang terjadi di atas. Media sebagai wahana penyampai informasi, memiliki dampak negatif yang besar apabila tidak mampu dipergunakan dengan baik. Solihin (2015) dan Mukaromah (2015) mengungkapkan terpaan iklan mendorong gaya hidup konsumtif masyarakat urban. Berdasarkan data
Kementerian Komunikasi dan Informatika (https://kominfo.go.id), sepanjang tahun 2017 tercatat ada 13.829 konten negatif berupa ujaran kebencian yang marak di media sosial, 6.973 berita bohong dan 13.120 konten pornografi. Selain itu, hingga 18 September 2017 terdapat 782.316 situs yang telah diblokir oleh pemerintah. Konten negatif yang menyebar di media sosial berupa ujaran kebencian, berita bohong dan sentimen bernada Suku, Agama, Ras dan Antar Golongan (SARA), berdampak besar pada pola pikir maupun sikap generasi muda, terutama di tingkat Sekolah Menengah Atas.

Literasi media sangat diperlukan untuk dapat menangkal berbagai fenomena negatif media yang terjadi. Literasi media merupakan "the ability to access, understand, \& create communications in variety contexts" (Buckingham, 2005). Literasi media memberikan panduan tentang bagaimana mengambil kontrol atas informasi yang disediakan oleh media atau dengan kata lain literasi media menekankan pada upaya memberikan kesadaran kritis masyarakat terhadap media.

Di Indonesia, literasi media merupakan salah satu dari 6 (enam) bagian Gerakan Literasi Nasional (GLN) sebagai prasyarat kecakapan hidup abad 21, yang bertujuan untuk menumbuhkembangkan budaya literasi pada ekosistem pendidikan mulai dari keluarga, sekolah, dan masyara-kat dalam rangka pembelajaran sepanjang hayat sebagai upaya untuk meningkatkan kualitas hidup (Kemdikbud, 2017). Demikian pentingnya literasi media, maka sudah seyogyanya literasi media diajarkan dan dimiliki sejak usia dini mulai dari lingkungan keluarga, untuk selanjutnya disinergikan dengan pendidikan di sekolah dan lingkungan masyarakat.

Literasi media di sekolah dilaksanakan dengan mengintegrasikannya dengan kegiatan intrakurikuler, kokurikuler dan ektrakurikuler. Pelaksanaannya dapat dilakukan di dalam kelas atau di luar kelas yang didukung oleh orang tua dan masyarakat (Kemdikbud, 2017). Kegiatan intrakurikuler dilaksanakan melalui mata 
pelajaran. Kegiatan kokurikuler dilaksanakan melalui kegiatan-kegiatan di luar sekolah yang terkait langsung dengan mata pelajaran. Sedangkan kegiatan ekstrakurikuler dilaksanakan melalui berbagai kegiatan yang bersifat umum dan tidak terkait langsung dengan mata pelajaran (Permendikbud Nomor 103 Tahun 2014 tentang Pedoman Pelaksanaan Pembelajaran pada Pendidikan Dasar dan Pendidikan Menengah). Literasi media berkaitan dengan pendidikan di sekolah telah diteliti dan dikembangkan oleh berbagai negara, seperti yang diungkapkan oleh Aufderheide \& Firestone (1992); Brown (1998); Alvermann, Moon, \& Hagood (1999); Cheung (2007); Cheung (2009); Arke \& Primack (2009); Gainer, Valdez-Gainer, \& Kinard (2009); Amory (2011); Bier, Schmidt, \& Shields (2011); Boske \& McCormack (2011); Domine (2011); DaCosta (2012); dan Belova \& Eilks (2016).

Di Indonesia, literasi media telah dilakukan melalui berbagai program di antaranya oleh 8 (delapan) lembaga yakni KIPPAS di Medan, Yayasan Sahabat Cahaya dan Remotivi di Jakarta, LeSPI di Semarang, Jurnal Celebes di Makassar, serta MPM, ECCD-RC, dan Centre for LEAD di Yogyakarta (Tim Peneliti Pusat Kajian Media dan Budaya Populer, 2013). Sementara program literasi media secara khusus di sekolah belum banyak dilakukan, dan umumnya hanya pada tingkat Pendidikan Anak Usia Dini (PAUD). Sementara di tingkat SMA, program literasi media yang penulis temukan ada di SMA Muhammadiyah 1 Kota Magelang berupa kegiatan ekstrakurikuler untuk kelas X, namun tujuan instruksional umum yang ada belum sampai menyentuh pada nilai-nilai Islam yang semestinya diterap-kan.

Literasi media harus ditanamkan dan disosialiasikan, namun juga harus tetap memperhatikan nilai-nilai yang berlaku di sebuah wilayah atau masyarakat. Di negara dengan berasas kapitalisme \& liberalisme, tentu berbeda cara atau titik fokus pengembangan literasi medianya dengan negara yang berasas Pancasila seperti di
Indonesia. Indonesia merupakan negara dengan muslim terbesar di dunia yakni sebesar 209 juta jiwa. Jumlah itu merupakan $13 \%$ dari seluruh umat muslim di dunia. Berdasarkan data tersebut, maka sudah sepatutnya nilai-nilai Islam menjadi rujukan dalam pendidikan literasi media, apalagi di sekolah-sekolah khusus yang menamakan dirinya sekolah Islam.

Sekolah Menengah Atas (SMA) merupakan jenjang sekolah dengan jumlah siswa dengan paparan internet tertinggi (APJII, 2016). Sementara itu, siswa di usia SMA akan atau telah memulai partisipasi aktif dalam kehidupan politik seperti misalnya pemilihan kepala daerah, kepala negara, dan dewan legislatif yang kerapkali riskan dengan adanya ujaran kebencian, berita bohong, dan kekhawatir-an tidak tepatnya memilih pemimpin seperti yang seharusnya dilakukan menurut ajaran agama Islam.

SMA Al Irsyad Satya merupakan salah satu representasi sekolah Islam di wilayah Bandung Raya. Beberapa karakteristik SMA Al-Irsyad Satya menjadikan sekolah ini memiliki kemudahan mengakses media lebih tinggi di banding sekolah lainnya, terutama terkait akses media asing.

Kegiatan pengembangan diri merupakan upaya pembentukan watak dan kepribadian peserta didik yang dilakukan melalui kegiatan pelayanan konseling berkenaan dengan masalah pribadi dan kehidupan sosial, kegiatan belajar, dan pengembangan karir, serta kegiatan ekstra kurikuler. Kegiatan ekstrakurikuler Pengembangan Diri (PD) merupakan salah satu jenis ekstrakurikuler yang ada di SMA Al-Irsyad Satya yang bertujuan untuk menguatkan berbagai kompetensi siswa terkait berbagai hal, salah satunya dalam literasi media bermuatan nilai-nilai Islam.

Hal ini menjadikan peneliti merasa perlu untuk mengembangkan sebuah desain kurikulum literasi media bermuatan nilainilai Islam pada kegiatan ekstrakuri-kuler PD yang diharapkan dapat relevan untuk dapat diterapkan di Sekolah Menengah 
Atas (SMA) khususnya SMA Al-Irsyad Satya.

\section{METODE PENELITIAN}

Metode yang digunakan dalam penelitian ini adalah Design \& Development (D \& D) tipe 1 berdasarkan Richey \& Klein (2005). Penelitian D \& D merupakan penelitian sistematis terkait proses desain, pengembangan, dan evaluasi dengan tujuan untuk membangun dasar empiris terhadap penciptaan produk atau alat dalam bidang instruksional maupun non-instruksional, serta penciptaan atau pengembangan sebuah model. Penelitian ini sesuai dengan D \& D tipe 1 karena memiliki tujuan utama menghasilkan produk berupa kurikulum literasi media berlandaskan nilai-nilai Islam di SMA AlIrsyad Satya yang belum pernah ada sebelumnya. Produk kurikulum tersebut terwujud dalam sebuah silabus kurikulum literasi media berlandaskan nilai-nilai Islam, yang dapat siap untuk digunakan di SMA Al-Irsyad Satya.

Terdapat tiga langkah dalam metode penelitian ini, yakni Analysis; Prototype development and testing; dan Prototype revision and retesting.

Pada tahap analysis peneliti merinci kompetensi literasi media berlandaskan nilai-nilai Islam berdasarkan studi literatur. Peneliti merinci daftar kompetensi literasi media, kemudian kompetensi-kompetensi tersebut disusun dalam kuesioner yang dibagikan kepada partisipan yakni seluruh guru di SMA Al-Irsyad Satya termasuk guru dengan jabatan tambahan seperti Kepala Sekolah dan Wakil Kepala Sekolah. Pada tahap ini peneliti menggali kompetensi yang dibutuhkan atau diharapkan dimiliki siswa, berdasarkan pertimbangan dari semua guru SMA Al-Irsyad Satya selaku pihak pengembang kurikulum di pihak satuan pendidikan melalui kompetensi-kompetensi apa saja yang dianggap sesuai, beserta saran/masukan terkait kompetensi yang perlu ditambahkan. Hasil dari analisis kebutuhan ini menjadi dasar untuk penyusunan desain kurikulum literasi media berlandaskan nilai-nilai Islam di SMA Al-Irsyad Satya.

Pada tahap prototype development and testing peneliti membuat desain kurikulum berdasarkan analisis kebutuhan yang diperoleh dan menghasilkan sebuah draf awal kurikulum literasi media berlandaskan nilai-nilai Islam di SMA AlIrsyad Satya berupa silabus pembelajaran. Komponen-komponen silabus terdiri dari tujuan pembelajaran berupa Kompetensi Dasar, Materi Pembelajaran, Kegiatan Pembelajaran, Penilaian Hasil Belajar, Alokasi Waktu, dan Sumber belajar.

Draf kurikulum berupa silabus literasi media berlandaskan nilai-nilai Islam diserahkan kepada ahli atau pakar yakni ahli kurikulum, ahli konten yang terdiri dari ahli literasi media dan ahli agama Islam, serta perwakilan SMA Al-Irsyad Satya sebagai end user. Ahli kurikulum dan perwakilan SMA Al-Irsyad Satya memberikan tanggapan terkait kurikulum yang dibuat, apakah relevan atau tidaknya, dengan memberikan check list pada setiap aspek kurikulum yang disusun, beserta masukan/saran apabila diperlukan di kolom saran/perbaikan. Relevansi yang dilihat adalah relevansi eksternal dan internal kurikulum. Semen-tara ahli konten memberikan penilaian terhadap konten/materi dalam kurikulum literasi media berlandaskan nilai-nilai apakah telah sesuai atau tidak dengan kriteria-kriteria yang ada, beserta saran perbaikan. Saat ditemukan ketidak jelasan dalam pengisian kuesioner yakni dibagian saran perbaikan, maka peneliti melakukan wawancara untuk memperjelas jawaban dalam kuesioner.

Kuesioner stakeholder review dianalisis data dengan menggunakan analisis deskriptif. Kemudian dilakukan perbaikanperbaikan pada komponen yang kurang layak atau tidak layak. Hasil perbaikan diserahkan kembali kepada para ahli dan perwakilan SMA Al-Irsyad Satya, hingga diperoleh draf akhir yang seluruhnya sangat sesuai/sangat relevan dan sesuai/ relevan, untuk kemudian diberikan tanda tangan validasi sebagai keterangan bahwa 
kurikulum telah mengalami perbaikan dan baik untuk dipergunakan.

Setelah dilakukan stakeholder review pertama, hasil dari review tersebut diperbaiki sesuai dengan catatan atau saran dari para stakeholder. Setelah diperbaiki, diperoleh draf kedua desain kurikulum literasi media berlandaskan nilai-nilai Islam, untuk kemudian direview kembali oleh para stakeholder, hingga dihasilkan draf akhir yang telah divalidasi dan layak untuk digunakan.

\section{HASIL PENELITIAN \\ Hasil}

Hasil penelitian pada analisis kebutuhan menunjukkan bahwa terdapat 71 indikator desain kurikulum literasi media bermuatan nilai-nilai Islam yang relevan untuk dipergunakan dan disusun dalam sebuah dokumen kurikulum. Pada komponen tujuan adalah tujuan pembelajaran berupa: Siswa dapat menjelaskan tujuan media bermuatan nilai-nilai Islam; Siswa dapat menjelaskan karakteristik media yang baik bermuatan nilai-nilai Islam; Siswa dapat menganalisis 3 program TV/kanal internet/media yang baik untuk ditonton bermuatan nilai-nilai Islam; Siswa dapat menganalisis 3 program TV/kanal internet/media yang tidak baik untuk ditonton bermuatan nilai-nilai Islam; Siswa dapat menunjukkan perilaku cerdas memilih media; Siswa dapat mempresentasikan perilaku cerdas memilih media; Siswa dapat mengidentifikasi ciri-ciri media yang berframing; Siswa dapat menjelaskan langkah-langkah tabayyun saat memperoleh informasi; Siswa dapat menunjukkan perilaku tabayyun saat memperoleh informasi; Siswa dapat mempresentasikan perilaku tabayyun saat memperoleh informasi; Siswa dapat menampilkan hafalan Alquran Al Hujurat ayat $6 \& 12$ beserta terjemahan-nya; Siswa dapat menampilkan hadits tentang tabayyun; Siswa dapat menunjuk-kan perilaku menjauhi zina; Siswa dapat menunjukkan perilaku menjauhi bullying melalui media; Siswa dapat menunjukkan perilaku kontrol diri dari sikap fanatisme;
Siswa dapat menunjukkan perilaku kontrol diri dari sikap konsumerisme; Siswa dapat menunjukkan perilaku kontrol diri dari sikap riya; Siswa dapat menunjukkan kontrol diri dari perilaku membuang waktu berlebihan saat menggunakan media; Siswa dapat menampilkan hafalan Al Quran surah Al Isra' ayat 26-27 beserta terjemahannya; Siswa dapat menampilkan hafalan Al Quran surah An Nur ayat 32 beserta terjemahannya; Siswa dapat menampilkan hafalan Al Quran surah Al Isra' ayat 32 beserta terjemahannya; Siswa dapat menjelaskan kandungan Al Quran surah Al Ashr ayat 1-3 dikaitkan dengan literasi media; Siswa dapat menampilkan hafalan hadits tentang perilaku fanatisme terhadap suatu kaum beserta kandungan-nya; Siswa dapat menampilkan Al Quran surah Al A'raaf ayat 80-81 beserta terjemahannya; Siswa dapat membuat sebuah karya positif melalui media; Siswa dapat membuat kampanye internet sehat di media mading sekolah; dan Siswa dapat membuat kampanye anti LGBT di media.

Pada komponen materi atau konten adalah konten berupa: Konsep tujuan media berdasarkan nilai-nilai Islam; Karakteristik media yang baik bermuatan nilai-nilai Islam; Contoh analisis 3 pro-gram TV/kanal internet/media yang baik untuk ditonton berdasarkan nilai-nilai Islam; Contoh analisis 3 program TV/kanal internet/media yang tidak baik untuk ditonton berdasarkan nilai-nilai Islam; Langkah-langkah tabayyun; Ciri-ciri media yang berframing; Al Quran Al Hujurat ayat 6 \& 12 beserta terjemahannya; Hadits tentang tabayyun; Perilaku menjauhi zina; Perilaku menjauhi bullying melalui media; Perilaku kontrol diri dari sikap fanatisme; Perilaku kontrol diri dari sikap konsumerisme; Perilaku kontrol diri dari sikap riya; Perilaku kontrol diri dari membuang waktu berlebihan saat menggunakan media; Hafalan Al Quran surah Al Isra' ayat 26-27 beserta terjemahannya; Hafalan Al Quran surah An Nur ayat 32 beserta terjemahannya; Hafalan Al Quran surah Al Isra' ayat 32 beserta terjemahannya; Kandungan Al Quran surah Al Ashr ayat 1- 
3 dikaitkan dengan literasi media; Hadits tentang perilaku fanatisme terhadap suatu kaum beserta kandungannya; Hafalan Al Quran surah Al A'raaf ayat 80-81 beserta terjemahannya; dan Karya positif melalui media.

Pada komponen strategi atau pengalaman belajar adalah strategi berupa: Pendekatan Kontekstual; Pendekatan Pemecahan Masalah; Pendekatan Konsep; Pendekatan Saintifik; Metode Ceramah Ekspositori; Metode Tanya Jawab; Metode Diskusi; Metode Resitasi (Pemberian Tugas); Metode Project Based Learning (PjBL); Metode Problem Based Learning $(P B L)$; Moda tatap muka In On In; Media ajar video/film; Media Ajar Powerpoint; Media Internet; Media Cetak; Media Lembar Kerja; dan Media Buku Monitoring.

Pada kegiatan ekstrakurikuler PD yang diperlukan di SMA Al-Irsyad Satya pada komponen evaluasi pembelajaran berupa: Tes uraian untuk mengukur pencapaian kognitif; Tes lisan berupa presentasi untuk mengukur pencapaian kognitif; Penilaian lembar monitoring kegiatan literasi media, yang divalidasi orang tua/guru untuk menilai kompetensi ranah afektif dan psikomotor; Penilaian proses dan Lembar Kerja saat kegiatan pembelajaran; Peniliaian presentasi siswa; dan Penilaian produk siswa.

Seluruh indikator yang relevan tersebut disusun menjadi sebuah dokumen kurikulum, dan setelah itu pada proses reviu stakeholder diperoleh hasil bahwa desain kurikulum literasi media bermuatan nilainilai Islam pada kegiatan ekstrakurikuler pengembangan diri di SMA Al-Irsyad Satya relevan untuk dipergunakan.

\section{Pembahasan}

Hasil relevansi analisis kebutuhan dengan nilai yang tinggi dapat diartikan bahwa indikator atau subkomponen dari tiap komponen kurikulum yang disusun dianggap sesuai atau dibutuhkan oleh para responden yakni seluruh guru, apabila diterapkan di SMA Al-Irsyad Satya. Hasil ini diperoleh melalui proses kajian sebelumnya (praanalisis kebutuhan), sehingga peneliti dapat menyusun daftar analisis kebutuhan yang tepat untuk ditawarkan saat analisis kebutuhan. Pra analisis kebutuhan merupakan tahapan dimana peneliti merumuskan daftar pernyataan atau indikator dalam kurikulum literasi media berdasarkan telaah terhadap berbagai hal, mencakup 4 komponen kurikulum yakni tujuan, materi/konten, strategi/pengalaman belajar, dan evaluasi pembelajaran. Hal yang dikaji antara lain kajian terhadap definisi literasi media, kajian terhadap sumber nilai-nilai Islam yakni Al Quran dan hadits Rasulullah SAW, kajian terhadap dokumen kurikulum 2013 sebagai manifestasi dari kurikulum abad 21, dan kajian terhadap kondisi atau karakteristik SMA Al-Irsyad Satya.

Pada kajian terkait definisi literasi media, Potter (2014) mengungkapkan bahwa untuk membuat sebuah desain literasi media, langkah awal adalah dengan membuat atau memutuskan sebuah definisi literasi media yang jelas dan kuat untuk digunakan. Tanpa definisi yang tepat, maka langkah untuk pembelajaran literasi media tidak akan efektif, sebagaimana diungkap oleh Thai (2014) yang menganalisis bahwa dari 45 jurnal literasi media, sebanyak 36\% tidak memiliki konseptualisasi yang jelas terkait media literasi, sehingga perlakuannya pun menjadi kurang optimal, misalnya hanya berfokus pada ranah kognitif semata. Dalam desain kurikulum ini, peneliti menggunakan atau mengkaji definisi literasi media dari ahli yang telah puluhan tahun terlibat dalam literasi media seperti Potter dan Buckingham, serta lembaga resmi literasi media seperti National Association for Media Literacy Education (NAMLE), dan disesuaikan pula dengan latar belakang penelitian ini sendiri.

Literasi media sebagaimana yang diungkap oleh Potter (2014) berhubungan dengan bagaimana khalayak dapat mengambil kontrol atas literasi media. Sementara Buckingham (2005) memaknai literasi media sebagai "the ability to access, understands, and creates commu-nications in variety contexts". Kemampuan untuk 
mengakses media merujuk pada kemampuan untuk menentukan konten media yang sesuai dengan kebutuhannya dan menghindar dari konten media yang tidak dibutuhkan. Sementara kemampuan memahami mengacu pada apa yang dilakukan oleh khalayak ketika menemukan informasi dan kemampuan menciptakan adalah kemampuan untuk menulis di media. Definisi yang serupa dengan Buckingham ini juga disampaikan oleh NAMLE yang menyebutkan bahwa literasi media merupakan kemampuan untuk mengakses, menganalisis, mengevaluasi, dan mengomunikasikan informasi dalam berbagai bentuk. Berdasarkan definisi-definisi tersebut, penulis mengambil kesimpulan bahwa literasi media merupakan kemampuan untuk mengakses dan mema-hami sebuah informasi yang disampaikan melalui media, sehingga individu yang menerimanya mampu mengontrol diri dari berbagai dampak negatif media, serta kemampuan untuk mengkomunikasikan informasi dalam berbagai bentuk media.

Sementara itu, kajian terkait sumber hukum Islam merupakan langkah agar kurikulum yang disusun tidak terlepas dari nilai-nilai Islam, karena bisa jadi hal yang dianggap benar secara keumuman namun tidak sesuai dalam syariat Islam. Kajian literasi media berlandaskan sumber hukum Islam berarti mengawinkan ayat-ayat $\mathrm{Al}$ Qur'an dan hadits yang ada dengan definisi literasi media sebagai kemampuan mengakses, memahami, dan mengkomunikasikan informasi. Salah satu contohnya, ayat Al Qur'an surat Al 'Alaq ayat 1-5 mengajarkan atau menganjurkan manusia untuk membaca. Membaca merupakan jendela ilmu. Dalam kaitannya dengan literasi media, membaca merupakan salah satu cara untuk mengakses informasi agar memperoleh ilmu pengetahuan seluasluasnya.

Membaca dalam kaitannya dengan literasi media juga dapat dimaknai dengan mencari informasi lain sebagai bentuk verifikasi atas informasi yang diterima, atau dalam Islam disebut dengan istilah tabayyun. Hal ini diperkuat dengan $\mathrm{Al}$
Qur'an surat Al Hujurat ayat 6 dan 12 yang memerintahkan manusia untuk melakukan tabayyun. Tabayyun sebagai langkah untuk mencari kejelasan tentang sesuatu hingga jelas dan benar keadaannya, menjadikan seseorang untuk meneliti dan menyeleksi suatu berita sebelum disampaikan kepada pihak lain, serta tidak secara tergesa-gesa dalam memutuskan suatu permasalahan baik dalam perkara hukum, kebijakan dan lain sebagainya hingga sampai jelas benar permasalahnnya. Tabayyun juga menjadi jalan agar manusia tidak berprasangka buruk sebagaimana hadits Rasulullah SAW untuk menjauhi prasangka buruk, karena prasangka butuk adalah sedusta-dusta ucapan.

Selanjutnya, literasi media juga menyangkut bagaimana kontrol diri individu atas media. Kajian terhadap ayat Al Quran dan hadist terkait kontrol diri dari perilaku negatif media di antaranya terhadap Al Quran surat Al Isra' ayat 26-27 terkait perilaku kontrol diri dari sikap boros; Al Ashr ayat 1-3 terkait kontrol diri dari perilaku membuang-buang waktu; An Nur ayat 32, Al Isra' ayat 32, dan Al A'raaf ayat 80-81 tentang perilaku kontrol diri dari zina dan perbuatan keji; hadits terkait fanatisme, dan beberapa hadits lainnya. Ayat Al Quran dan hadits tersebut menjadi fondasi utama agar kurikulum literasi media yang didesain menjadi kokoh sebab merupakan sumber hukum utama dalam Islam, di mana seluruh target kurikulum ini yakni siswa SMA Al-Irsyad Satya merupakan Muslim.

Setelah mengkaji definisi literasi media, mengkaji Al Quran dan hadits Rasulullah SAW, peneliti melakukan kajian terhadap dokumen kurikulum 2013, sebagai manifestasi dari konsep pendidikan abad 21. Hasil dari kajian terhadap dokumen kurikulum 2013 di antaranya adalah perlunya penyusunan desain kurikulum yang memperhatikan keseimbangan antara ranah kognitif, afektif, dan psikomotor dalam komponen tujuan. Selain itu, kurikulum yang disusun haruslah mengupayakan pembelajaran yang menjadikan siswa aktif sehingga akan menghasilkan 
pembelajaran yang bermakna. Strategi berupa pendekatan dan metode yang disarankan dalam kurikulum 2013 berupa strategi yang menitikberatkan pada keterampilan di abad 21 yakni kemampuan berpikir kritis, berpikir kreatif, berkomunikasi, dan berkolaborasi. Dan pada ranah evaluasi pembelajaran, haruslah berupa pendekatan autentik agar penilaian dapat dengan tepat mengukur tujuan yang diharapkan.

Dalam upaya menyusun daftar analisis kebutuhan, selain dari kajian terhadap definisi literasi media, kajian terhadap Al Qur'an dan hadits, kajian terhadap dokumen kurikulum 2013, juga dilakukan kajian terhadap kondisi atau karakteristik target yakni siswa SMA AlIrsyad Satya. Nathanson \& Yang (2003) mengungkapkan bahwa untuk membuat sebuah desain literasi media, perlu adanya analisis terhadap target atau sasaran seperti pola perilaku, bakat, dan pencapaiannya. Kajian dilakukan terhadap data-data tentang permasalahan siswa berkenaan dengan efek media pada khususnya, visi misi sekolah yang menjadi salah satu rambu dalam penyusunan atau pengembangan kurikulum di satuan pendidikan SMA AlIrsyad Satya, serta kajian terhadap dokumen satuan pendidikan SMA AlIrsyad Satya terkait indikator-indikator yang telah ada dalam mata pelajaran lainnya agar tidak terjadi tumpang tindih.

Kajian yang diperoleh dalam langkah-langkah pra analisis kebutuhan menghasilkan 27 kompetensi atau tujuan pembelajaran yang dijadikan daftar dalam identifikasi/analisis kebutuhan. Perumusan tujuan-tujuan pembelajaran merupakan pijakan utama untuk menyusun daftar indikator pada komponen-komponen selanjutnya yakni materi/konten, strategi/ pengalaman belajar, dan evaluasi pembelajaran.

Berbagai tujuan dalam desain literasi media menjadikan perbedaan dalam hasil belajar yang diharapkan. Sebagai contoh, dari berbagai publikasi jurnal yang dikaji, terdapat desain kurikulum literasi media yang berfokus pada peningkatan kemam- puan kognitif (Moore, dkk, 2000), seperti kemampuan berpikir kritis (Scharrer, 2006; Vande Berg, Wenner \& Gronbeck, 2004; Vooijs \& van der Voort, 1993a, 1993b). Beberapa desainer kurikulum juga ada yang berfokus pada tujuan kemampuan memproduksi media (Banerjee \& Greene, 2006; dan Brown, 2000), ada juga yang berfokus pada peningkatan pengetahuan tentang media (Webb \& Martin, 2012). Sementara yang lainnya, ada yang bertujuan untuk membentuk motivasi pada siswa (Hoffner, 1997; Linz, Fuson, \& Donnerstein, 1990; Slone \& Shoshani, 2006), dan sebagian besar sebagai upaya membentuk pola perilaku kontrol diri dari konten media seperti bulliying dalam media (Rosenkoetter, et al., 2004).

Pada pra analisis kebutuhan dalam penelitian ini, tujuan pembelajaran yang dirumuskan dapat dikelompokkan menjadi empat yakni kemampuan untuk mengakses media (access), kemampuan untuk memahami media (understand), dan kemampuan untuk mengkomunikasikan informasi dalam berbagai bentuk (create communications in variety context). Kemampuan mengakses media dalam hal ini terkait dengan kemampuan untuk menentukan konten media yang sesuai dengan kebutuhannya, dan menghindar dari konten media yang tidak dibutuhkan. Dengan kata lain, kemampuan yang diharapkan terkait dengan memahami konsep media, serta cerdas dalam memilih media. Tujuan pembelajaran yang dirumuskan dalam kemampuan mengakses media di antaranya adalah: 1) Siswa dapat menjelaskan tujuan media berlandaskan nilai-nilai Islam; 2) Siswa dapat menjelaskan karakteristik media yang baik berlandaskan nilai-nilai Islam; 3) Siswa dapat menganalisis 3 program TV/chanel internet/media yang baik untuk ditonton berlandaskan nilai-nilai Islam; 4) Siswa dapat menganalisis 3 program $\mathrm{TV} / \mathrm{chanel}$ internet/media yang tidak baik untuk ditonton berlandaskan nilai-nilai Islam; 5) Siswa dapat menunjukkan perilaku cerdas memilih media berlandaskan nilai-nilai Islam; 6) Siswa dapat mempresentasikan 
perilaku cerdas memilih media; dan 7) Siswa dapat mengidentifikasi ciri-ciri media yang berframing.

Sementara itu kemampuan terkait memahami (understand) media berkenaan dengan kemampuan saat siswa mendapat informasi atau paparan media. Dalam hal ini kemampuan yang diharapkan berkenaan dengan kemampuan untuk melakukan verifikasi informasi (tabayyun) dan kemampuan untuk mengontrol diri dari dampak informasi atau media. Tujuan pembelajaran yang dirumuskan dalam kemampuan terkait memahami media ini di antaranya adalah: 8) Siswa dapat menjelaskan langkah-langkah tabayyun saat memperoleh informasi; 9) Siswa dapat menunjukkan perilaku tabayyun saat memperoleh informasi; 10) Siswa dapat mempresentasikan perilaku tabayyun saat memperoleh informasi; 11) Siswa dapat menampilkan hafalan Al Quran Al Hujurat ayat $6 \& 12$ beserta terjemahannya; 12) Siswa dapat menampilkan hadits tentang tabayyun; 13) Siswa dapat menunjukkan perilaku menjauhi zina; 14) Siswa dapat menunjukkan perilaku menjauhi bullying melalui media; 15) Siswa dapat menunjukkan perilaku kontrol diri dari sikap fanatisme; 16) Siswa dapat menunjukkan perilaku kontrol diri dari sikap konsumerisme; 17) Siswa dapat menunjukkan perilaku kontrol diri dari sikap riya; 18) Siswa dapat menunjukkan kontrol diri dari perilaku membuang waktu berlebihan saat menggunakan media; 19) Siswa dapat menampilkan hafalan Al Qur'an surat Al Isra' ayat 26-27 beserta terjemahannya; 20) Siswa dapat menampilkan hafalan Al Qur'an surat An Nur ayat 32 beserta terjemahannya; 21) Siswa dapat menampilkan hafalan Al Qur'an surat Al Isra' ayat 32 beserta terjemahan-nya; 22) Siswa dapat menjelaskan kandungan $\mathrm{Al}$ Qur'an surat Al Ashr ayat 1-3 dikaitkan dengan literasi media; 23) Siswa dapat menampilkan hafalan hadits tentang perilaku fanatisme terhadap suatu kaum beserta kandungannya; dan 24) Siswa dapat menampilkan Al Qur'an surat Al A'raaf ayat 80-81 beserta terjemahan-nya.
Selanjutnya, kemampuan untuk mengkomunikasikan informasi dalam berbagai bentuk (create communications in variety context), memiliki fokus pada kemampuan siswa untuk menghasilkan karya-karya positif terkait media, dalam hal ini adalah kemampuan berda'wah (menyampaikan informasi kebaikan) dan ber-amar ma'ruf nahi munkar menggunakan media, sehingga tujuan pembelajaran yang dirumuskan yakni: 25) Siswa dapat membuat sebuah karya positif melalui media; 26) Siswa dapat membuat kampanye internet sehat di media mading sekolah; dan 27) Siswa dapat membuat kampanye anti LGBT di media.

Sebagaimana hasil kajian dokumen kurikulum 2013, tujuan pembelajaran literasi media yang dirumuskan disusun dengan memperhatikan keseimbangan antara ranah kognitif, afektif, dan psikomotor, di mana dari 27 tujuan pembelajaran, terdapat 9 tujuan pada ranah kognitif yakni tujuan pembelajaran nomor 1), 2), 3), 4), 7), 8), 12), 22), dan 23). Sementara itu terdapat 8 tujuan pembelajaran pada ranah afektif yakni pada nomor 5), 9), 13), 14), 15), 16), 17), dan 18). Sedangkan pada ranah psikomotor, terdapat 10 tujuan pembelajaran yakni pada nomor 6), 10), 11), 19), 20), 21), 24), 25), 26), dan 27).

Setelah indikator-indikator berupa daftar kompetensi dalam komponen tujuan disusun, selanjutnya disusunlah daftar materi pembelajaran, diikuti dengan penyusunan daftar strategi/pengalaman belajar. Dalam penyusunan strategi/pengalaman belajar, dokumen kurikulum 2013 merupakan acuan utama. Strategi yang digunakan adalah pendekatan, metode, atau media yang bervariasi dan dianjurkan untuk menghasilkan pembelajaran siswa aktif, seperti pendekatan berbasis masalah, metode kooperatif, media film, dan lain sebagainya. Sebagaimana diungkapkan dalam berbagai jurnal literasi media, bahwa kurikulum literasi media diutamakan untuk mengaktifkan siswa seperti contohnya aktivitas siswa mengkritisi sebuah film atau video (Doolittle, 1980), menulis esai (Linz, 
Fuson, \& Donnerstein, 1990), latihan tentang empati (Nathanson \& Yang, 2003), berdiskusi kelompok (Slone \& Shoshani, 2006), dan memproduksi sebuah pesan di media (Banerjee \& Greene, 2006).

Setelah strategi/pengalaman belajar disusun,selanjutnya dilakukan penyusunan indikator evaluasi pembelajaran.

Pada komponen strategi, nilai hasil analisis kebutuhan yang paling tinggi adalah pada indikator "metode Problem Based Learning" (PBL). Metode PBL merangsang siswa untuk dapat berpikir kritis. Hal ini sesuai karena berbagai definisi literasi media yang ada sebenarnya merujuk pada upaya untuk memberikan kesadaran kritis bagi khalayak ketika berhadapan dengan media (Tim PKMBP, 2013). Pada PBL, peserta didik bekerja dalam tim untuk memecahkan masalah dunia nyata (real world). PBL dilakukan dengan adanya pemberian rangsangan berupa masalah-masalah. PBL menjadikan permasalahan sebagai kajian, permasalahan sebagai penjajakan pemahaman, permasalahan sebagai contoh, permasalahan sebagai bagian yang tak terpisahkan dari proses, dan permasalahan sebagai stimulus aktivitas autentik. Berdasarkan hasil penelitian, PBL memiliki kelebihan di antaranya melalui PBL terjadi pembelajaran bermakna karena peserta didik yang belajar memecahkan suatu masalah, maka mereka akan menerapkan pengetahuan yang dimilikinya atau berusaha mengetahui pengetahuan yang diperlukan. Selanjutnya, dalam situasi PBL, peserta didik mengintegrasikan pe-ngetahuan dan keterampilan secara simultan dan mengaplikasikannya dalam konteks yang relevan. Selain meningkat-kan kemampuan berpikir kritis, PBL juga menumbuhkan inisiatif peserta didik dalam bekerja, motivasi internal untuk belajar, dan mengembangkan hubungan interpersonal dalam bekerja kelompok.

Sementara itu, nilai relevansi indikator strategi yang paling rendah adalah ceramah ekspositori. Hal ini dapat terjadi karena metode ceramah dianggap metode yang membosankan, dapat menyebabkan ngantuk, dan membuat siswa pasif. Akan tetapi hasil nilai relevansinya masih berada dalam kategori relevan, sehingga dapat dipergunakan dalam desain kurikulum. Hal ini juga dapat diperkuat dengan ceramah ekspositori merupakan ceramah yang tidak hanya guru berbicara, namun guru menggunakan alat bantu seperti media powerpoint, dan lainnya. Metode ceramah ekspositori dapat dipergunakan untuk kegiatan atau aktivitas pembelajaran berupa penguatan-penguatan materi dari guru agar siswa mandapat penekanan lebih terkait materi literasi media.

Pada komponen evaluasi, hasil nilai relevansi tertinggi adalah lembar monitoring dan penilaian produk siswa, yakni sebesar 93 dengan kategori sangat relevan. Hal ini sesuai dengan kondisi di mana hasil analisis kebutuhan di komponen tujuan yang tertinggi adalah di ranah afektif. Evaluasi pembelajaran menggunakan lembar monitoring merupakan penilaian untuk kompetensi di ranah afektif seperti perilaku kontrol diri terhadap media. Dengan menggunakan lembar monitoring, perilaku yang muncul pada diri siswa tidak hanya bersifat perilaku di sekolah saja, namun lebih dari itu, perilaku ini dapat muncul di mana saja dan kapan saja, seperti misalnya di rumah, ataupun di kegiatan sekolah di jam-jam istirahat, dan lain sebagainya. Sehingga, pihak yang memberikan validasi ataupun penilaian bisa terdiri dari orang tua, wali kelas, atau bahkan teman sebaya. Pelibatan orang tua dan teman sebaya pada literasi media, dapat menghasilkan efek yang lebih kuat (Nathanson \& Yang, 2003).

Sementara itu, hasil nilai relevansi pada indikator "Tes pilihan ganda untuk menilai aspek kognitif" memiliki nilai yang rendah dengan kategori kurang relevan. Hal ini dapat dipahami mengingat tes pilihan ganda memiliki beberapa kelemahan di antaranya adalah kurang mampu mengukur kemampuan riil siswa mengingat adanya kesempatan untuk menembak jawaban. Sehingga, indikator ini tidak dimasukkan sebagai bagian dari komponen evaluasi desain kurikulum literasi media 
berlandaskan nilai-nilai Islam di SMA AlIrsyad Satya.

Selanjutnya, terkait kefaktualan dan keaktualan materi didasarkan pada ketepatan penjabaran materi yang didasarkan pada sumber yang terpercaya (faktual) dan bersifat kebaruan (actual). Sebagai contoh, materi terkait membuat kampanye anti LGBT mengandung unsur kefaktualan berupa sumber hukumnya langsung dari ayat Al Qur'an dan hadits, serta keaktualan mengingat semakin maraknya kasus LGBT sehingga perlu adanya upaya preventif pada diri setiap siswa. Kesesuaian materi dengan tingkat kemampuan siswa juga didasarkan pada misalnya untuk surat Al Ashr ayat 13, bukan pada hafalan melain-kan pada kandungannya. Siswa SMA Al-Irsyad Satya seluruhnya telah hafal surat tersebut, sehingga materi pembelajaran adalah berupa kandungan ayat dikaitkan dengan literasi media. Hal ini tentu sesuai dengan tingkat kemampuan siswa SMA yang mampu untuk menguraikan keterkait-an dan kandungan dari sebuah ayat Al Qur'an.

Kesesuaian pendekatan pemecahan masalah dengan tujuan pembelajaran didasarkan pada tujuan kurikulum literasi media untuk menjadikan siswa memiliki kemampuan untuk mengakses, memahami, dan mengkomunikasikan media dalam berbagai bentuk. Berdasarkan 27 tujuan pembelajaran yang disusun pada desain kurikulum, terdapat contoh-contoh tujuan yang mengharapkan adanya pemecahan masalah seperti kampanye internet sehat dan membuat karya positif. Pada tujuan tersebut, siswa diharapkan untuk terlatih untuk berpikir kritis, kreatif dalam menyelesaikan permasalahan atau tugas yang diberikan oleh guru melalui pembelajaran literasi media. Demikian pula halnya kesesuaian pemilihan pende-katan berbasis proyek dengan tujuan pembelajaran, dimana tujuan pembelajaran di antaranya adalah "Siswa mampu membuat karya positif melalui media" yang mana dalam hal ini mengharapkan produk terkait karya di media.

Kesesuaian pendekatan saintifik dengan tujuan pembelajaran didasarkan pada amanat kurikulum 2013 bahwa pendekatan saintifik merupakan pendekatan yang tepat untuk mencapai keterampilan di abad 21. Langkah 5 M (Mengamati, Menanya, Mengumpulkan informasi, Mengolah informasi, dan Mengkomunikasikan) akan dapat merang-sang kemampuan berpikir siswa seperti kemampuan berpikir kritis dan kemampuan komunikasi, sehingga relevan dengan tujuan pembelajaran literasi media yang disusun.

Kesesuaian pemilihan media dengan tujuan pembelajaran didasarkan pada jenisjenis media yang digunakan seperti film, internet, lembar kerja, media cetak, dan lain sebagainya yang disesuaikan dengan kebutuhan yakni dalam hal ini adalah tujuan pembelajaran. Seperti misalnya dalam tujuan pembelajaran "Siswa dapat mengidentifikasi ciri-ciri media berframing" digunakan media internet agar siswa dapat mencari sebuah media misalnya video yang mengandung framing.

\section{PENUTUP}

Kurikulum literasi media berlandaskan nilai-nilai Islam di SMA Al-Irsyad Satya terdiri dari empat komponen yakni tujuan, materi/konten, strategi/pengalaman belajar, dan evaluasi pembelajaran. Pada hasil analisis kebutuhan, nilai rata-rata relevansi seluruh item pernyataan memiliki kategori sangat relevan. Pada desain kurikulum, terdapat 71 indikator yang digunakan sebagai bahan penyusunan setiap komponen kurikulum. Pada review stakeholder, nilai rata-rata relevansi eksternal dan internal desain kurikulum memiliki kategori sangat relevan. Berdasarkan hal ini maka desain kurikulum literasi media berlandaskan nilai-nilai Islam di SMA AlIrsyad Satya layak untuk digunakan.

Rekapitulasi hasil review stakeholder yang menunjukkan bahwa antara tujuan pembelajaran dengan analisis kebutuhan dan visi misi sekolah termasuk dalam kategori sangat relevan disebabkan oleh daftar tujuan pembelajaran yang ada pada desain kurikulum literasi media berlandaskan nilai-nilai Islam yang disusun 
seluruhnya bersumber dari tujuan pembelajaran yang memiliki kategori relevan dan sangat relevan dalam hasil analisis kebutuhan.

Bagi pihak sekolah dalam hal ini adalah SMA Al-Irsyad Satya, sebagai satuan pendidikan pelaksana kurikulum, perlu adanya tim pengembang kurikulum khusus yang berupaya untuk melakukan perbaikan-perbaikan terutama setelah desain kurikulum ini dilaksanakan. Setelah pelaksanaan atau implementasi kurikulum literasi media, pihak sekolah perlu melakukan evaluasi program terkait kurikulum ini sendiri. Hal-hal yang ditemukan dalam evaluasi program, dapat menjadi perbaikan untuk pelaksanaan atau pengembangan kurikulum literasi media di tahun-tahun berikutnya.

Bagi Peneliti selanjutnya, implementasi kurikulum ini dapat dijadikan penelitian lanjutan, untuk mengetahui efektivitas kurikulum literasi media. Sementara bagi peneliti di bidang desain lainnya, khususnya terkait kurikulum literasi media, perlu adanya analisis kebutuhan hingga ke tingkat siswa dan orang tua, karena dalam penelitian ini baru menjaring kebutuhan berdasarkan data dari guru saja.

\section{UCAPAN TERIMA KASIH}

Terima kasih penulis ucapkan kepada berbagai pihak yang telah membantu pelaksanaan penelitian ini, terutama kepada pihak SMA Al-Irsyad Satya yang telah memberikan kesempatan untuk mengeksplor berbagai hal terkait ekstra-kurikuler pengembangan diri, serta kepada kementerian pendidikan dan kebudayaan selaku pemberi dana sehingga penelitian ini berjalan dengan lancar.

\section{DAFTAR PUSTAKA}

Alvermann, D. E., Moon, J. S., \& Hagood, M. C. (1999). Popular culture in the classroom: teaching and researching critical media literacy. USA: International Reading Association.

Amory, A. (2011). pre-service teacher development: a model to develop critical media literacy through computer game-play. Education as Change, 15 (S1), hlm. S111-S122.

Arke, E. T. \& Primack, B. A. (1999). Quantifying media literacy: development, reliability, and validity of a new measure. Educational Media International, 46 (1), hlm. 53-65.

Asosiasi Jasa Penyelenggara Internet Indonesia (APJII). (2016). Data survey pengguna internet di Indonesia tahun 2016. [Online]. Diakses dari: https://www.apjii.or.id/ Aufderheide, P. \& Firestone, C. M. (1992). Media literacy: a report of the national leadership conference on media literacy. USA: The Aspen Institute.

Banerjee, S. C., \& Greene, K. (2006). Analysis versus production: adolescent cognitive and attitudinal responses to antismoking interventions. Journal of Communication, 56 (1), hlm. 773794.

Belova, N. \& Eilks, I. (2016). German teachers' views on promoting scientific media literacy using advertising in the science classroom. International Journal of Science and Mathematics Education, 14 (7), hlm. 1233-1254.

Bier, M. C., Schmidt, S. J., \& Shields, D. (2011). School-based smoking prevention with media literacy: a pilot study. Journal of Media Literacy Education, 2 (3), hlm. 185-198.

Bobby, G. (2015). Pragmatisme, materialisme, dan hedonisme. [Online]. Diakses dari http://www.kompasiana.com/gabriel bobby/pragmatisme-materialismedanhedonisme_55edad0c2623bdf40b c10e50.

Boske, C. \& McCormack, S. (2011). Building an understanding of the role of media literacy for latino: a high school students. The High School Journal, 94 (4), hlm. 167-186.

Brown, J. A. (1998). Media literacy perspectives. Journal of Communication, 48 (1), hlm. 44-57. 
Brown, J. D. (2000). Adolescents' sexual media diets. Journal of Adolescent Health, 27(2), hlm. 35-40.

Buckingham, D. (2005). The media literacy of children and young people. London: Centre for the Study of Children, Youth, and Media Institute of Education, University of London.

Cheung, C. K. (2007). The teaching of moral education through media education. The Asia PacificEducation Researcher, 16 (1), hlm. 61-72.

Cheung, C. K. (2009). Education reform as an agent of change: the development of media literacy in Hong Kong during the last decade. Comunicar, 16 (32), hlm. 95-109.

DaCosta, K. O. (2012). Media literacy education program evaluators: what's the job description, again? Journal of Media Literacy Education, 4 (3), hlm. 266-271.

Domine, V. (2011). Think global, act local: expanding the agenda for media literacy education in the United States. Library Trends, 60 (2), hlm. 440-453

Gainer, J. S., Valdez-Gainer, N., \& Kinard, T. (2009). The elementary bubble project: exploring critical media literacy in a fourth-grade classroom. The Reading Teacher, 62 (8), hlm. 674-683.

Hoffner, C. (1997). Children's emotional reactions to a scary film: the role of prior outcome information and coping style. Human Communication Research, 23, hlm. 323-341.

Kementerian Komunikasi dan Informasi. (2014). Riset Kominfo dan UNICEF mengenai perilaku anak dan remaja dalam menggunakan internet, siaran pers. [Online]. Diakses dari: https://kominfo.go.id.

Kementerian Pendidikan dan Kebudayaan. (2017). Panduan Gerakan Literasi Nasional (GLN). Jakarta: Kemendikbud.

Komisi Perlindungan Anak Indonesia (KPAI). (2016). Bank data perlindungan anak-data kasus berdasarkan klaster perlindungan anak, 2011-2016. [Online]. Diakses dari

http://bankdata.kpai.go.id/tabulasidata/data-kasus-per-tahun/datakasus-berdasarkan-klasterperlindungan-anak-2011-2016.

Linz, D., Fuson, I. A., \& Donnerstein, E. (1990). Mitigating the negative effects of sexually violent mass communications through preexposure briefings. Communication Research, 17, hlm. 641-674.

Moore, J., DeChillo, N., Nicholson, B., Genovese, A., \& Sladen, S. (2000). Flashpoint: an innovative media literacy intervention for high-risk adolescents. Juvenile and Family Court Journal, 51(2), hlm. 23-34.

Mukaromah, H. (2015). Masyarakat hipper-reality (kajian pola konsumtif remaja desa Bajing Kulon atas handphone). (Skripsi). Jurusan Komunikasi Penyiaran Islam, Fakultas Dakwah, Institut Agama Islam Negeri Purwokerto.

Nathanson, A. I., \& Yang, M-S. (2003). The effects of mediation content and form on children's responses to violent television. Human Communication Research, 29 (1), hlm. 111-134.

Permendikbud Nomor 103 Tahun 2014 tentang Pedoman pelaksanaan pembelajaran pada pendidikan dasar dan pendidikan menengah.

Potter, W. J. (2014). Guidelines for media literacy interventions in the digital age. Medij. Istraž, 20 (2), hlm. 5-29.

Richey, R. C. \& Klein, J. D. (2005). Developmental research methods: creating knowledge from instructional design and development practice. Journal of Computing in Higher Education, 16 (2), hlm. 23-38.

Rodhan, N. R. F. (2006). Definitions of Globalization: A Comprehensive Overview and A Proposed Definition. Geneva: Geneva Centre for Security Policy. 
Rosenkoetter, L. I., Rosenkoetter, S. E., Ozretich, R. A., \& Acock, A. C. (2004). Mitigating the harmful effects of violent television. Applied Developmental Psychology, 25, hlm. 25-47.

Scharrer, E. (2006). "I noticed more violence:" The effects of a media literacy program on critical attitudes toward media violence. Journal of Mass Media Ethics, 21, hlm. 69-86.

Slone, M., \& Shoshani, A. (2006). Evaluation of preparatory measures for coping with anxiety raised by media coverage of terrorism. Journal of Counseling Psychology, 53, hlm. 535-542.

Solihin, O. (2015). Terpaan iklan mendorong gaya hidup konsumtif masyarakat urban. Jurnal Ilmu Politik dan Komunikasi, 5 (2), hlm. 41-50.

Thai, C. (2014). Development of a scale for evaluating media literacy interventions. Santa Barbara, CA: University of California at Santa Barbara.

Tim Peneliti Pusat Kajian Media dan Budaya Populer (PKMBP). (2013). Model-model gerakan literasi media dan pemantauan media di Indonesia. Yogyakarta: Penerbit PKMBP.

Vande Berg, L. R., Wenner, L. A., \& Gronbeck, B. E. (2004). Media literacy and television criticism: Enabling an informed and engaged citizenry. American Behavioral Scientist, 48, hlm. 219-228.

Vooijs, M. W., \& van der Voort, T. H. A. (1993a). Larning about television violence: the impact of a critical viewing curriculum on children's attitudinal judgments of crime series. Journal of Research and Development in Education, 26, hlm. 133-142.

Vooijs, M. W., \& van der Voort, T. H. A. (1993b). Teaching children to evaluate television violence critically: the impact of a dutch schools television project. Journal of
Educational Television, 19(3), hlm. 139-152.

Webb, T., \& Martin, K. (2012). Evaluation of a us school-based media literacy violence prevention curriculum on changes in knowledge and critical thinking among adolescents. Journal of Children \& Media, 6, hlm. 430449. 